For citation: Kumo, K., Korgun, I. A., Koval, A. G. \& Trofimenko, O. Yu. (2018). Foreign Trade and Regional Inequality: The Case of the Russian Federation. Ekonomika Regiona [Economy of Region], 14(3), 884-895

doi 10.17059/2018-3-14

JEL: R11; F160

UDC 339.5; 332.1

K. Kumo ${ }^{\text {a) }}$, I. A. Korgun ${ }^{\text {b) }}$, A. G. Koval ${ }^{\text {c) }}$, O. Yu. Trofimenko ${ }^{\text {c) }}$

a) Hitotsubashi University (Tokyo, Japan)

b) Hankuk University of Foreign Studies (Seoul, South Korea)

c) Saint-Petersburg State University (Saint-Petersburg, Russian Federation; e-mail: a.koval@spbu.ru)

\title{
FOREIGN TRADE AND REGIONAL INEQUALITY: THE CASE OF THE RUSSIAN FEDERATION ${ }^{1}$
}

\begin{abstract}
An impact of foreign trade on national inequality levels is one of the most discussed topics both by public, politicians and academics. This paper contributes to this discussion by focusing on the role of foreign trade in the Russian Federation during its rapid economic transformation in 1990-2010. During this period, the trade-led growth model has helped to raise country-average levels of income. But simultaneously, it seemingly triggered greater inequality in income appropriation between different social groups. Looking into causality between foreign trade and this observed income disparity from the regional perspective will help us to understand the poverty problem associated with income inequality better and enhance the effectiveness of policies of the Russian government targeting income re-distribution. In particular, this research aims to answer a question whether during 1990's-2000's increasing openness to foreign trade was pro-poor on the regional level or not. Another point of interest is whether the distributional impact of growing foreign trade on incomes in Russian regions had been positive or negative. Several hypotheses for the Russian Federation are tested in the paper. First, higher openness to foreign trade improved income distribution in the Russian regions. Second, globalization of regions as a result of a more active foreign trade benefited individuals in the middle-income decile. This follows an idea that trade liberalization cuts living costs and raises living standards. Third, regions with larger rural population will tend to have more uneven income distribution. This follows from the neo-classical assumption that in rural areas a poverty burden tends to be larger. Active involvement in the trade of agricultural products might improve income distribution in such regions. Additionally, the share of dependent population among households must affect poverty headcount or the depth of poverty as previous studies on poverty determinants naturally suggested.
\end{abstract}

Keywords: poverty, inequality, foreign trade, trade openness, regional economy, gross regional product, income distribution, Russia, economic transformation, economic development

\section{Introduction}

In 1995, World Bank Conference on Development Economics concluded that 'unequal income distribution and its associated poverty problems remain central issues for the future' $[1$, p.38]. Twenty years have passed since then, but the problem remains far from to be solved, and many studies continue to point out a global trend towards growing inequality both at national and regional levels [2-5]. Inequality remains one of the most significant problems in the Russian social and economic development as the country has seen the highest growth rate of GINI coefficient from 1990-s till 2000-s comparing with other G20 members [10].

\footnotetext{
${ }^{1}$ This research was supported by the Russian Foundation for Basic Research (RFBR) №17-02-00688 “Transformation of Russian Foreign Economic Policy in a Changing Geopolitics".
}

Academic research does not give a definite answer to a question about sources of uneven income distribution. Often international trade is blamed for the income gaps [6] but statistical data are mixed. During recent 25 years, countries like Latin America, Eastern Europe, the Commonwealth of Independent States (CIS) introduced active trade liberalisation policies as a part of their economic reform packages. Their effect caused fundamental changes in national trade patterns and contributed to the overall rapid rise in international trade levels [7-8]. On the one hand, comparing to 1990, when respective laws for trade liberalisation were introduced, the levels of observed inequality measured by the GINI coefficient increased substantially [9]. According to the World Bank official statistics, in Russia, for example, the GINI level went up from 0.259 in 1990 to 0.422 in 2007. Even in the US, the trend was upward from 0.34 in the mid-1980's, to 0.38 in the mid-2000's. 
On the other hand, higher participation of these countries in international trade created additional sources of income for the governments leaving more room for infrastructure and social spending. For instance, Brazil managed to bring down GINI from 0.605 in 1990 to 0.549 in $2007^{1}$ thanks to various state programs.

Evidences regarding the effect of trade on within-country income distribution are far from comprehensive. The studies that addressed the issue have so far been focusing on between-country differences or international comparisons of countries [11-14]. Recently, a lot of empirical research examining the question of whether more foreign trade worsens or improves income distribution among social groups in a single country came out but their results are rather controversial as well. While most of them find a correlation between trade and inequality, they present inverted effects and admit that inferring causality is complicated due to endogeneity problems. For example, some authors declare that there is a strong correlation between trade and income, and trade and inequality in the cross-section of countries; countries with higher trade openness tend to have higher living standards and lower income inequality [15]. Others argue that the interplays between trade and the adoption of technology may constitute an important mechanism leading to a possible increase in income differentials in the liberalizing countries [16]. Some studies show that international trade benefits the firms that produce the high-quality products, while trade decreases the profits for those that barely export their products and those that serve only their individual domestic markets [17].

In general, the cross-country studies demonstrate that trade openness generates the increase of regional inequality, however, a higher integration in the international trade could neutralize the negative effect [18]. Thus, the recent studies of Brazil and India cases indicate that in India trade openness led to the regional inequality while the effect in Brazil was opposite [19]. That means an obvious need to investigate trade-inequality links by each country case in order policy makers could better treat the interregional development and income distribution.

The most noticeable reason for social disparities under trade openness is differentiation in the competitiveness of regions due to their industrial specialization [20]. In the case of Russia, the regional inequality increased during the transition

\footnotetext{
${ }^{1}$ The World Bank official statistics. Retrieved from: http://data worldbank.org (date of access: 08.05.2018).
}

from planned to market economy. The economic transformation evoked structural changes in industrial performance of regions [21]. One of the core drivers for such changes was a greater integration of Russia in international trade chains and specialization on raw materials export that created the imbalance between oil and gas producing regions and manufacturing regions [22]. However, in the majority of studies trade openness per se usually was not in the focus of research on the regional inequality in Russia, even that experts argue that one of the main dimensions of increasing polarization was export shares of regions [23].

So far, there is little doubt that more studies devoted to single country cases are needed for policy-makers and societies, in general, to understand the issue better. This research seeks to contribute the debate by investigating regional dimensions of the inequality problem in the Russian Federation. The paper presents results of an empirical investigation on the impact of trade on income distribution in Russia. It analyses causal relations between openness to trade (largely facilitated by economic reforms of the 1990s), and inequality levels in Russian regions during 20002012. The difficulty to deal with the problem is partly due to the fact that over time poverty line changes and it is not always easy to compare its past and present levels [24]. In the academic community, there is no agreement on a single definition of poverty levels mainly due to their fluid nature [25]. There is even less consensus on the impact of trade on national poverty levels as various studies present different, and often contradictory, empirical results. Some even argue that inequality is less subject to changing levels of poverty; on the contrary, it may lead to growth and give a broader picture of gains from trade for society [26].

This research contributes to the existing studies in several aspects. First, it examines trends in inequality in Russia in relation to the trade openness. Second, causal links between regional inequality and trade openness in the Russian Federation are tested. Finally, based on the obtained results, the paper argues that adequate trade policy can help to improve observed inequality levels because trade benefits social groups in the middle-income decile the most.

\section{Dimensions of Income Distribution in Russia}

The problem of income distribution is generally discussed in connection to inequality and poverty. While each of the three represents an individual object of research, they co-exist and one can cause another. Due to such interconnected- 


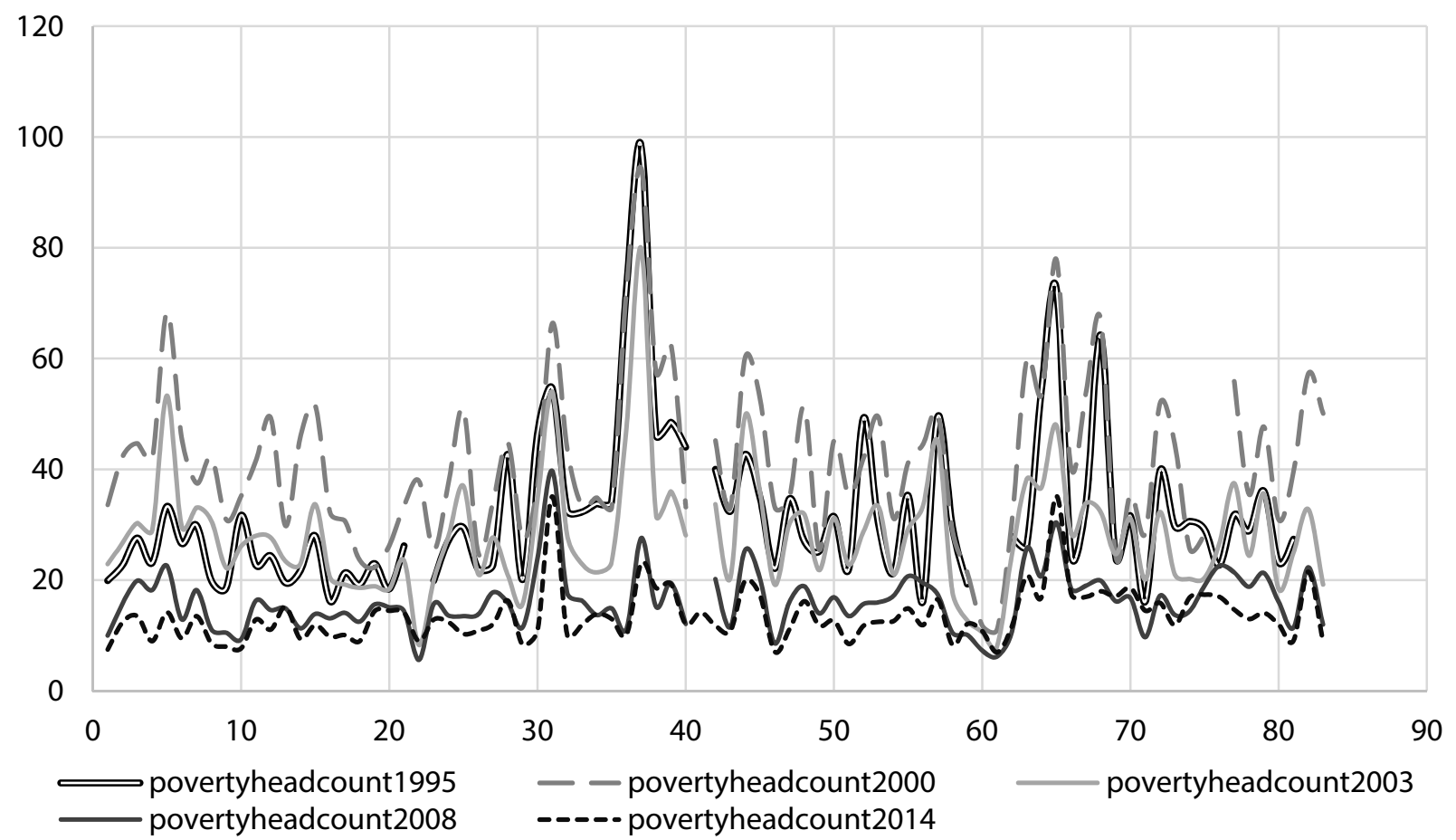

Fig. 1. Trends in poverty headcount in Russia, various years. Source: Russian Federal Statistical Service

ness, this part discusses income distribution in Russia in relation to inequality and poverty.

For many years the issues of wealth distribution and income inequality in Russia were among key national priorities. Indeed, for the most part of the 1990s the country experienced a severe economic crisis accompanied by impressive growth of foreign trade. During the first years of transition, inequality increased tremendously, and more than $20 \%$ of the population lived below the poverty line [27]. Inequality remains huge up to now: top 5 percent of the Russian population in 2015 owned 82 percent of the total national wealth ${ }^{1}$. The problem also has a strong regional dimension. According to Rosstat, the difference in the average per capita income between the richest Nenets Autonomous Okrug (one of the leading regions in terms of mineral resources) and Kalmykia (with the highest share of agriculture in GRP) exceeds 5 times $^{2}$.

One should also take into consideration income disparities within the regions. Interesting enough, the wealthier ones demonstrate a wider gap. In particular, according to the Bank of Finland Institute for Economies in Transition, income dis-

\footnotetext{
${ }^{1}$ Credit Suisse Global Wealth Databook 2015, 148, Retrieved from: http://delangemars.nl/wp-content/uploads/2015/10/ global-wealth-databook-20151.pdf (date of access: 09.10.2017). ${ }^{2}$ Srednedushevyye denezhnyye dohody po subektam Rossiyskoy Federatsii [Average monetary per capita income on territorial subjects of the Russian Federation]. (2014). Rosstat. Retrieved from: http://www.gks.ru/free_doc/new_site/population/urov/ urov_11sub.htm (date of access: 09.10.2017). (In Russ.)
}

tribution in the capital region was more uneven, than elsewhere in Russia, and a greater proportion of the population lived in poverty than the national average. As a group, families with small children were the worst off; $20 \%$ of Muscovites kids live in families classified below the poverty line [28].

Russian snapshot of a social wellbeing differs depending on whether it is looked at from the perspective of either poverty trends or inequality dynamics. So, in 2000's Russia succeeded in a considerable reduction of the poverty levels taken as a poverty headcount. As shown in Fig. 1, where the $X$ axis depicts Russian regions from 1 to 83 and the $Y$ axis - poverty headcount, number of poor in Russian regions reached a maximum in 2000 . By 2008, the level of poverty reduced considerably and remained at the same or slightly lower level through 2014. More importantly, it seems that variation in poverty headcount between various regions that used to be quite big in 1995 narrowed. Trend lines in poverty headcounts for both 2008 and 2014 are much smoother that the ones for 1995 and 2000. In other words, during 2000's Russia succeeded in reducing regional poverty levels as well as in narrowing the cross-regional gap.

In contrast to poverty headcount, income distribution seems to become more uneven over the same period. As captured by the Fig. 2, a share held by higher and lower $20 \%$ of population in almost all regions has grown by 2012 (the last year for which data are available) comparing to its lev- 


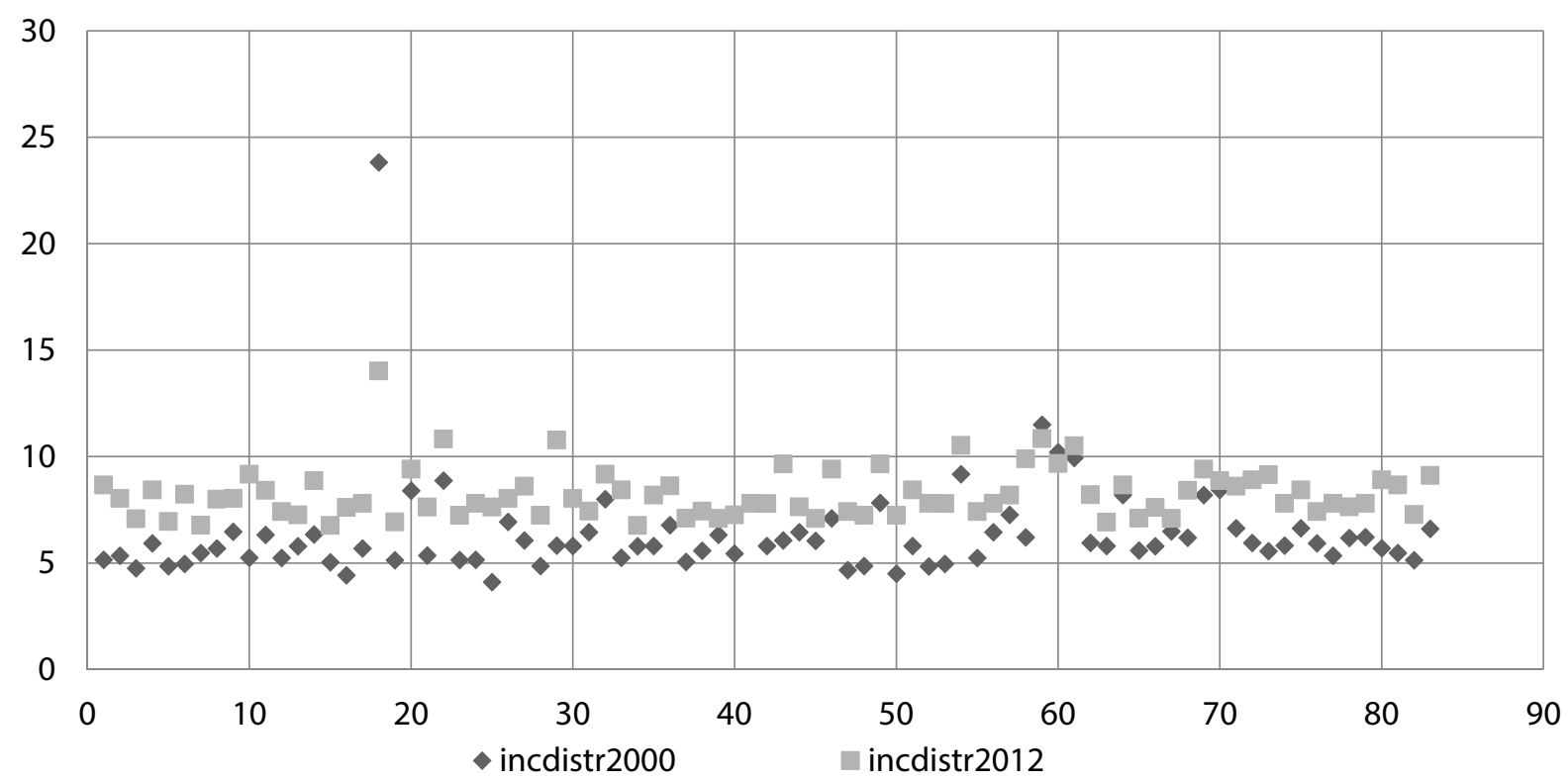

Fig. 2. Ratio of the share of income held by fifth and first $20 \%$ in 2000 and 2012 in Russian regions. Source: Russian Federal Statistical Service

els in 2000. The only exception has been Moscow (number 18), that reported a significant reduction in income discrepancy. All in all, in 2012 incomes of the upper $20 \%$ of the population in Russian regions were 8.25 times higher than incomes of the lower $20 \%$, in 2000 the figure was 6.36. Thus, after 2000 incidences of poverty in Russian regions diminished, at the same time, the income distribution became more uneven.

In 1990-2010's, Russia came through a fundamental economic transformation in which trade played a central role [29]. Trade-led growth model helped to raise the country-average levels of income but, simultaneously, it triggered greater inequality in income appropriation between social groups [30]. This problem is more severe on the regional level since 83 administrative regions (excluding Crimea and Sevastopol) of the country vary substantially in an observed income distribution and income level.

This development demonstrates a necessity to discuss problems of income distribution in connection to poverty. Lower levels of poverty do not automatically mean that all social groups enjoy equal access to benefits from the economic growth, in general, and benefits from foreign trade, in particular. As Emma Aisbett [23] points out income inequality may lead to a lack of economic opportunities and limit the productive capacity of economic agents. Conversely, if a country's economy grows slowly and cannot bring a fast reduction in poverty levels through rapidly rising income levels, measures aimed to make the distribution of income more even will help to deal with the poverty problem [25].

\section{Trends in Trade Openness} and Poverty Problem in Russian Regions

Russia regions show remarkable variation in their openness to foreign trade measured as a share of export plus import in gross regional products. As of 2013, in some regions, it was almost 0 while in others it was $40-60 \%$ or even higher (Fig. 3). Generally speaking, low levels of trade openness are the characteristic of the Southern Republics like Chechen or Ingush. High levels are common for resource-reach regions in the North (like Tumen) or large cities like Moscow or SaintPetersburg. Interestingly enough, in 2013, the levels of trade openness in almost all regions were lower than in 2000. It might be naturally assumed that the major reason has been the Great Recession that broke out in 2008.

A question that naturally arises here relates to how regions with higher levels of trade openness in 2000 when the level of poverty in Russia reached maximum, performed in terms of income distribution. To explore this issue, we constructed a chart that shows the relationship between the trade openness level in 2000 and income distribution in 2012, the last year for which data are available (Fig. 4). As it turns out, there is no clear pattern that would allow to conclude that regions with a higher level of trade openness had higher or lower levels of income discrepancy between fifth and first $20 \%$. Some of the regions with very low and very high volume of foreign trade in 2000 had a very low of income discrepancy in 2012. Thus, the impact of trade on inequality in Russian regions seems to be not a clear one. 


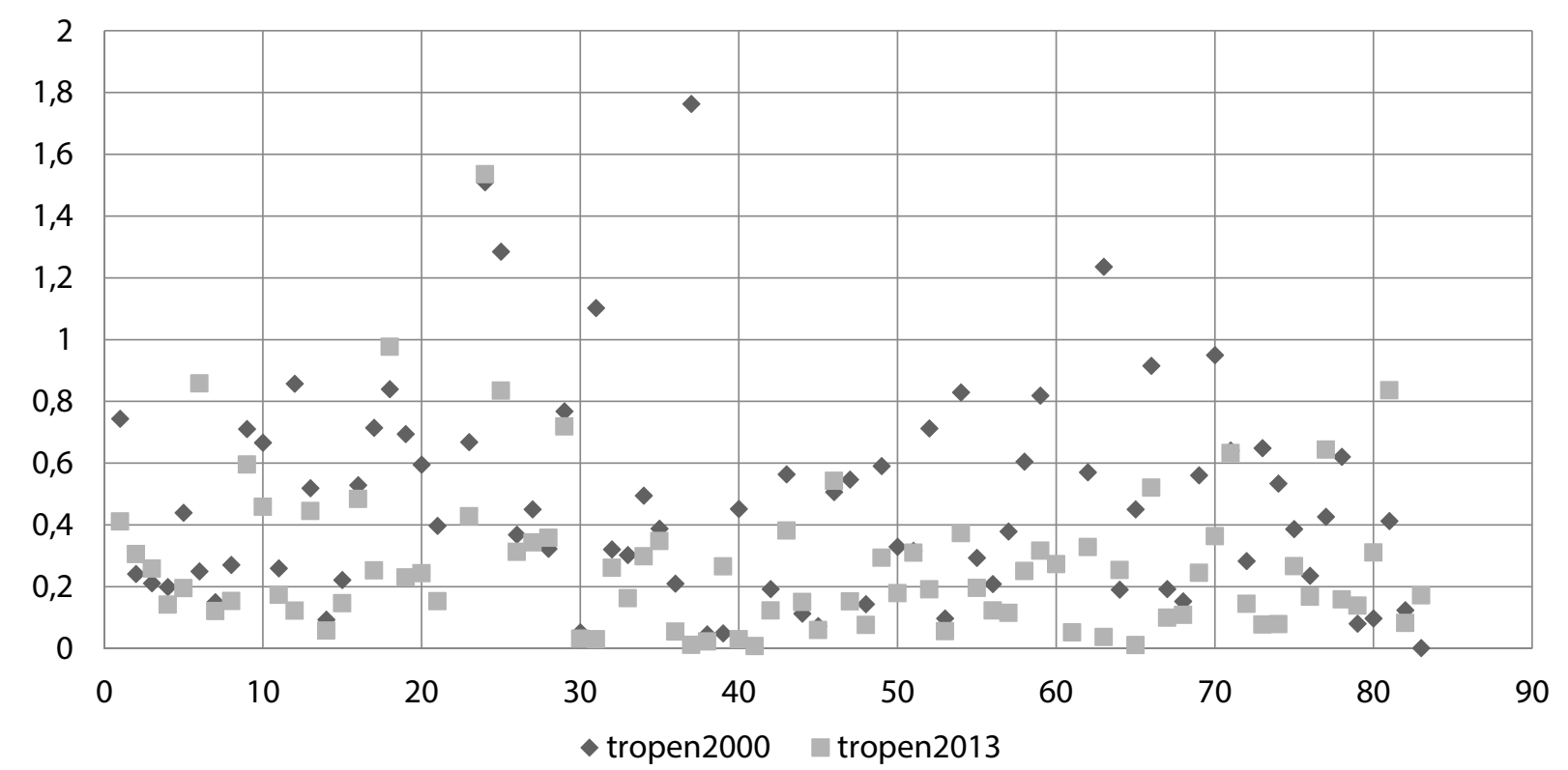

Fig. 3. Levels of trade openness in Russian regions in 2000 and 2013,\%. Source: Russian Federal Statistical Service

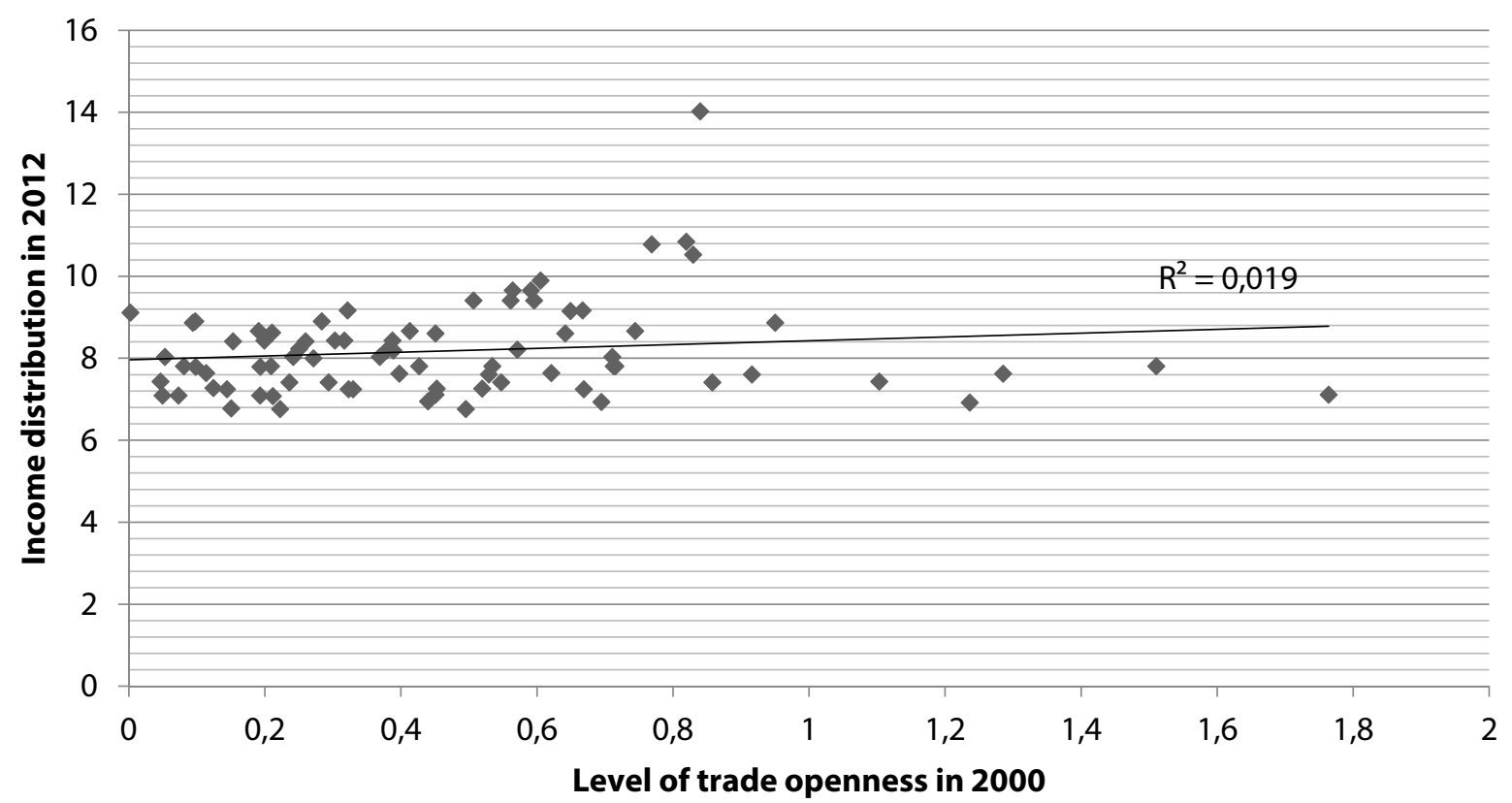

Fig. 4. Trade openness and income inequality in Russian regions

As it was mentioned beforehand, the problem of unequal income distribution in Russia emerged since the Soviet Union collapse and appeared to be much more difficult to solve than previously thought. Gorodnichenko et al. [31] while addressing inequality took into account the production of food by households that had a large equalizing effect on income and consumption. They also found that underreporting of income, wage payment delays, and some other features might explain some of the inequality trends. Denisova [32] observed a large variation in poverty rates across Russian regions due to the diversity of economic situations across regions in Russia, reflected by huge variations in per capita gross regional products, in growth rates, in levels of wages and in unemployment rates.

Fedorov [33] using a polarization index based on inequality decomposition, argued that the main dimensions of increasing polarization were not so much the "West - East" or the "Ethnic Russian - National Republics" divides, but factors such as export shares of regions or the relative sizes of their capitals.

The regional dimension of poverty in Russia was also addressed by the World Bank. The study pointed out large regional differences in living standards, as well as the urban-rural ones and warned that "if growth is not distributed evenly, then the poverty impact will be attenuated" [34]. 
The authors of the report estimated that trade and FDI liberalization, which were a part of the WTO accession package, is likely to have a significant positive impact on growth, and hence, on the sustained poverty reduction; but specify that the positive impact of FDI reforms will be greater than that of tariff reduction.

Later Rutherford and Tarr [35] developed a seven-region comparative static computable general equilibrium model of Russia to assess the impact of accession to the World Trade Organization and, in general, supported the findings of the above-mentioned report. They estimated that all deciles of the population in all federal regions of Russia can be expected to gain significantly, but mainly due to foreign direct investment attraction. Distribution impacts within regions would be flat for the first nine deciles. But the richest decile of the population in the three regions that attract a bulk of foreign investment would benefit much more than the other nine representative households in those regions.

In 2008, when Rutherford and Tarr published their results, nobody could predict that the impact of Russia's WTO accession on trade liberalization would be largely blocked by the sanctions imposed on Russia and its countersanctions as well as by some other developments. The most recent studies even cover the impact of economic sanctions on income inequality of target states. Afesorgbor and Mahadevan [36], on the basis of empirical evidence, argue that the target states should be cautioned about ignoring sanctions' effects on income distribution. They also claim that it is a combination of financial and trade sanctions which produces the greatest harm in widening an income inequality.

The bulk of Russian publications devoted to the inequality among various Russian territories and challenges of its overcoming mainly deals with the use of budget and regional policies. The authors criticize the existing approaches of state regional policy, arguing that it hardly takes into consideration differences existing among Russian areas [37]. They also indicate that the reliability of regional statistic is rather low, especially on the population's income and GRP. The latter is due to the institutional reasons. In particular, leading national companies could initially register in one region and then move to another. Hence their financial reports might change GRPs dramatically (for example, Gazpromneft is registered in St. Petersburg since 2006, before that its headquarter was located in Omsk). In addition to that, till 2005, there were so-called internal offshores with artificially high GRPs. Zubarevich [38] also argues that the budg- etary reform undertaken in the mid 2000s resulted in disproportions in the state budget revenues and high dependency of some regional budgets upon the federal one (in Chechnya and Ingushetia, the share of federal transfers in consolidated regional budgets almost reached $90 \%$ in 2013).

Even though poverty and inequality in Russian regions have been addressed in the economic literature, there is a room for additional studies. The analysis of existing publications shows that the problem under review has various sources and dimensions: Soviet Union collapse followed by a dramatic decline in production and severe economic crises, failures of state regional and fiscal policies, etc. There are several ways to improve the situation. Active involvement of the Russian regions in a foreign trade might be one of the solutions.

\section{Data and Methodology}

A general model proposed by Rodriguez-Pose [39] to estimate the effect of trade on equality was used to test for our hypotheses (1).

$$
\text { Inequality }_{i t}=a+\sum B x_{i t}+e_{i t}
$$

where Inequality is the level of inequality in a region $i$ at $a$ time $t$ and $x$ is a vector of independent variables conditioning the distribution of income in any given region $i$ at time $t$. Then we transform this model by introducing variables for trade, geography and factor endowment. Their choice was founded on the ideas by the New Economic Geography (NEG) developed by Krugman [40], Krugman and Fujita [41] and the work on trade and growth by Frankel \& Romer [42]. The NEG core-periphery framework sees differences in relative factor endowments as the result of the non-homogeneity of physical geography. Accordingly, income distribution is linked to relative foreign market access. When relatively wealthy regions are also those with a greater degree of accessibility, increases in trade are likely to contribute to existing inequalities. In contrast, when poorer regions have a market accessibility advantage, foreign trade is likely to improve inequality levels Rodriguez-Pose [39].

The specification estimated with OLS fixed effects takes the following form

$$
\begin{aligned}
& \text { Ineq }_{(\text {upper } 20 \% / \text { lower } 20 \%)}=\alpha+\beta_{1} \ln G R P+ \\
& +\beta_{2} \text { tropen }_{(\text {import }+ \text { export } / G R P)}+\beta_{3} \text { manuf }+ \\
& +\beta_{4} \text { unemprate }+\beta_{5}^{\text {res } 1}+\beta_{6} \text { infra }+\varepsilon .
\end{aligned}
$$

Ineq stands for the income distribution, it is a ratio of the share of income held by the fifth $20 \%$ of population to the first $20 \%$ of population in each region. The higher share would mean higher inequality as more income will flow to a wealth- 
ier part of the population. This ratio was directly calculated from data on income distribution by quintiles that are provided by Russian Statistical Service for the period 2000-2012.

LnGRP is Gross Regional Product of each region in the corresponding year. It is introduced to reflect the process of economic development. Data for LnGRP also cover 2000-2012.

Tropen is trade openness, which is measured as the sum of exports and imports divided by GRP in a given year over the period 2000-2012. Because Russian Statistical Service provides regional data on foreign trade measured in US dollars and data on GRP measured in Russian roubles, we had to convert data for GRP into US dollar using an average RUR/USD exchange rate in the given year as a basis and make direct calculations for trade openness of each region.

An indicator of trade share in GRP is an imperfect measure of the region's trade policy because it includes not only changes in the regulatory environment in the particular region (like changes in the level of tariffs and quotas and the like) but also changes in other factors like transportation costs, world demand and others. Perhaps the direct introduction of trade policy measures could better reflect real changes in the trade openness. However, using tariff rates for estimation may represent even bigger challenges because they do not include such factors as sanitary, labor, environmental restrictions. Therefore, it seems better to use trade to GRP ratio as a measure of trade openness because it is a more comprehensive indicator.

To control for the regional differences in types of economies, shares of manufacturing (manuf) and resource (res1) sectors were introduced into the analysis. Temporal change in the manufacturing-to-agriculture composition can influence the region's prospects for growth in general and its trade potential in particular. In the regions with a higher share of manufacturing inequality levels can be lower. But in Russia, many regions are dependent on the resource sectors that represent also major trading industries. To control for the presence of significant resource sectors, a dummy res 1 for regions with the share of resource sector exceeding $10 \%$ is introduced. Data for manuf and res1 are for the period 2000-2012.

Other factors might contribute to determining the link between trade and regional inequality as well. The potential problem here could result from trade endogeneity. For example, access to education may influence the intensity of trade in the given region. While many studies have found evidences on the positive relationship between trade, human development and inequality, the introduction of data on schooling as a proxy for education level differences between Russian regions would not bring meaningful results because of a very small variation. Russian regions share very similar characteristics of the education systems that remain largely state governed. Perhaps, data on endowments in the trade-related skills like proficiency of English and other foreign languages could be more relevant. Unfortunately, data availability represents a big problem here as comprehensive statistics remains largely unavailable.

To deal with potential trade endogeneity, a variable for infrastructure (infra) was introduced into the specification. Considering the vastness of Russian geographical space and long distances to borders with foreign partners, the level of infrastructure development could critically influence regions ability to trade. It also could be assumed that the better endowments in infrastructure for a particular region, the more even will be its distribution of trade benefits.

Infra denotes interregional differences in access to foreign markets. We could use physical distance or simple road density indicator but that would be a very crude measure of infrastructure development. Instead, we chose to follow the approach suggested by Rodriguez-Pose [39] and construct a special index that would better capture variation between regions in infrastructure development. The index was calculated as a sum of the railway and road in kilometres divided by the square root of the population during 2000-2012 and then multiplied by 100 . By assumption, this index proxies for the average transportation costs of a region, opportunities for international shipments and customs facilities. By design, this index also helps to address the problem of trade endogeneity.

During our sample period, the number of administrative regions in Russia has changed. The data for the years preceding those changes were adjusted to reflect several cases of the mergers between larger and smaller regions. The total number of regions is 83 and each region represents a panel; variables vary across panels and across years. Meanwhile, there are gaps in data for certain regions, which is especially the case for Southern republics, thus, we have a partially unbalanced panel.

Finally, to estimate how trade openness affects regional inequalities, OLS with fixed effect, as well as IV method are applied. Following Barro [43], the analysis also uses lagged levels of GRP as an instrument for the current GRP in order to address an errors-in-variable issue. Estimation with 
instrumental variable brings minor changes to the main outcome from the OLS analysis.

\section{Findings}

This section presents results of testing on the effect of trade openness on income inequalities in 83 Russian regions. Table 1 summarizes the results of OLS with the region fixed effects. When trade is considered as a free-standing variable (specification 1 Table 1), there seems to be an inverse link between changes in trade openness and regional income inequality as the variable on trade is statistically significant and has a negative sign. However, when the natural logarithm of GRP is introduced into the equation, the coefficient becomes insignificant and loses its influence. Instead, the coefficient on GRP is statistically significant and has a positive effect on inequality. This outcome is neither surprising nor contradicts to other findings. It generally suggests that economic growth induces social inequality, especially in the early stages of development ${ }^{1}$.

Trade openness becomes a meaningful predictor of income discrepancy when controls for manufacturing and resource sectors are added (specification 4). The coefficient on trade openness is significant at $5 \%$ level and has a negative sign as in specification 1 , but its absolute value is smaller. The coefficient on the resource sector is significant too and has a negative sign. Thus, in regions where the share of the resource sector exceeds $10 \%$, the levels of inequality tend to be lower than in regions with the smaller resource sectors. This finding deserves a special attention because, in many instances, the export of resources tends to be associated with higher inequalities.

When a control for infrastructure is introduced (specification 5), the coefficient on trade openness rises slightly but keeps its negative sign. The effects of variables for the resource sector and GRP are in line with other estimations but the coefficient on infrastructure did not obtain any serious results. Variables on manufacturing and unemployment rate are also statistically insignificant. Thus, the results of the estimation with the region fixed effect can be summarized in the following way. The only variable that consistently obtains statistical significance is GRP, the influence of trade seems to be important but confined to other factors.

\footnotetext{
${ }^{1}$ We confirmed that the same logic applies to Russia's case when a square root of the natural logarithm of GRP was introduced into equation. Square root of a variable shows changes in the dependent variable when independent variable changes by one unit. The coefficient on the squared $\ln G R P$ is statistically significant and equaled.
}

In order to check for the appropriateness of the fixed effect estimations, the Hausman test was performed. The probability Prob $>$ chi $2=0.0000$ shows in the direction of the fixed effect but, at the same time, there is a sign of the bias. Gennaioli, La Porta, de Silanes, Shleifer [44] point out that differences in institutions or culture are small within countries which can lead to a large bias at the regional level especially in small samples in estimations with fixed effect. In order to correct for the potential bias, we re-estimate the model by instrumenting the current level of GRP with its previous level, i. e. lnGRP is lagged by one year.

Test statistics for underidentification, weak identification as well as Hansen J statistic for overidentification of all instruments produced in the first-stage regression confirm the validity of the instruments ${ }^{2}$. Therefore, we can proceed with reporting the results. The outcome of the re-estimation is given in Table 2 specification 2 . The only variable that keeps its sign and statistical significance is lnGRP. The effect of GRP seems to be even stronger when compared with results for fixed effect estimation. Trade openness and resource sector are no longer significant predictors of the inequality. But, the share of the manufacturing sector, the level of the unemployment rate and index infrastructure are statistically significant at $1 \%$ level and have expected signs. A higher share of manufacturing industries in the regional economy seems to affect positively distribution of income, while unemployment contributes to uneven distribution. Also, in the regions with more developed infrastructure income discrepancy tends to be lower than in the regions with poor or insufficient roads. These results seem to be intuitively correct because under open trade manufacturing could create more employment opportunities. Employment is particularly important in Russia where wages and salaries remain the major source of income for the majority of population in working age. Better infrastructure provides access to foreign markets and could open access to benefits from trade for a larger number of economic agents. Also, taking into account existing large inter-regional variation in types of economies in Russia, infrastructure could be an important factor in lowering regional inequalities.

As a robustness check for the estimations with IV method, the model is estimated with OLS. The results are in line with the results from the IV test-

\footnotetext{
${ }^{2}$ Kleibergen-Paap rk LM statistic is $C h i-s q(1) \mathrm{P}-v a l=0.0000$; The Angrist-Pischke (AP) first-stage chi-squared and F statistics are tests of underidentification and weak identification reject the null with Prob $>F=0.0000$, Hansen's J statistic returns the results that equation is exactly identified.
} 
Table 1

Fixed effect estimation results

\begin{tabular}{|c|c|c|c|c|c|}
\hline VARIABLES & $(\mathbf{1})$ ineq & $(\mathbf{2})$ ineq & (3) ineq & (4) ineq & (5) ineq \\
\hline $\operatorname{lngrp}$ & & $0.897^{* * *}$ & $0.884^{* * *}$ & $0.897^{* * *}$ & $0.894^{* * *}$ \\
\hline & & $(0.0318)$ & $(0.0397)$ & $(0.0490)$ & $(0.0506)$ \\
\hline tropen & $-0.379^{* * *}$ & -0.124 & -0.172 & $-0.232^{* *}$ & $-0.260^{* *}$ \\
\hline manuf & $(0.125)$ & $(0.0916)$ & $(0.109)$ & $(0.110)$ & $(0.116)$ \\
\hline & & & & 0.00184 & 0.00174 \\
\hline unemprate & & & & $(0.00314)$ & $(0.00327)$ \\
\hline & & & -0.00606 & -0.00835 & -0.00857 \\
\hline res1 & & & $(0.0111)$ & $(0.0125)$ & $(0.0134)$ \\
\hline infra & & & & $-0.110^{* *}$ & $-0.124^{* *}$ \\
\hline & & & & $(0.0526)$ & $(0.0554)$ \\
\hline Constant & $7.646^{* * *}$ & $-3.048^{* * *}$ & $-2.862^{* * *}$ & $-2.954^{* * *}$ & -0.00125 \\
\hline & $(0.0529)$ & $(0.381)$ & $(0.536)$ & $(0.672)$ & $(0.00260)$ \\
\hline Observations & 972 & 972 & 904 & 831 & $(0.702)$ \\
\hline R-squared & 0.010 & 0.478 & 0.465 & 0.422 & 771 \\
\hline Number of id & 83 & 83 & 77 & 77 & 0.425 \\
\hline
\end{tabular}

Standard errors in parentheses ${ }^{* * *} p<0.01,{ }^{* *} p<0.05,{ }^{*} p<0.1$.

Results of estimation with IV and OLS

\begin{tabular}{|c|c|c|}
\hline VARIABLES & (1) ineq & (2) ineq \\
\hline $\operatorname{lngrp}$ & $1.076^{* *}$ & $1.062^{* * *}$ \\
\hline & $(0.0674)$ & $(0.0475)$ \\
\hline tropen & 0.165 & 0.188 \\
\hline & $(0.165)$ & $(0.159)$ \\
\hline manuf & $-0.0235^{* * *}$ & $-0.0223^{* * *}$ \\
\hline & $(0.00640)$ & $(0.00440)$ \\
\hline unemprate & $0.0227^{* *}$ & $0.0238^{* *}$ \\
\hline & $(0.00622)$ & $(0.00985)$ \\
\hline infra & $-0.0116^{* * *}$ & $-0.0125^{* * *}$ \\
\hline & $(0.00295)$ & $(0.00272)$ \\
\hline res1 & 0.0513 & 0.0504 \\
\hline & $(0.105)$ & $(0.102)$ \\
\hline Constant & $-4.786^{* * *}$ & $-4.604^{* * *}$ \\
\hline & $(0.778)$ & $(0.645)$ \\
\hline Observations & 700 & 771 \\
\hline R-squared & 0.517 & 0.500 \\
\hline
\end{tabular}

Standard errors in parentheses ${ }^{* * *} p<0.01,{ }^{* *} p<0.05,{ }^{*} p<0.1$.

ing. The model seems to work in the same direction when regional GINI indicators are used as a dependent variable instead of the ratio in the share of income held by the fifth and first $20 \%$ of population.

Overall, the result of the empirical analysis does not allow for any clear conclusion regarding the effect of trade openness on regional inequalities in Russia during 2000-2012. One of the obstacles seems to be a difficulty in isolating the effect of the trade from the effect of other variables. The effect of trade is conditional on the effect of other factors among which transport infrastructure has a key role. However, the analysis provides evidence that under the condition of the open trade positive effect of both manufacturing and infrastructure on income distribution is stronger ${ }^{1}$.

\section{Conclusions and Policy Recommendations}

The analysis shows that even though the involvement into the international trade, at first sight, seems to be an important factor of inequality breakthrough for Russian regions, the deeper look shows that the level of GRP and unemployment, as well as the development of manufacturing sector and infrastructure, appear to be more significant for equal income distribution. This indirectly supports the findings of Rutherford and Tarr [35] that pointed FDI - not trade - as a key driving force for additional gains for the Russian population resulting from the WTO accession. Indeed, foreign direct investments might stimulate industrial and infrastructural developments, as well as to increase labor force earnings to the certain level. Therefore, policies aimed at FDI attraction to Russian regions should take into consideration the need to widen the geography of inward FDI.

Budgetary transfers actively used by Russian government definitely flatten out regional differ-

\footnotetext{
${ }^{1}$ When estimating the model with IV method excluding variable for the trade openness manufacturing and infrastructure obtain smaller coefficients.
} 
ences. As Rodríguez-Pose [39] points out, spatial inequality likely to be more severe in countries with a weaker redistributive capacity of the central government and/or with fewer provisions for interregional transfers. Such a situation is not the case of the Russian Federation. The country definitely has the abilities to reallocate funds (mainly generated by the mineral resources export) among its territories. In the short run, such policy attenuates the spatial differences. Above-mentioned transfers include social benefits to low-income population groups. Since the share of poor people is higher in the backward regions, interregional income inequality tends to decrease.

At the same time, in the longer run, more attention should be paid to the creation and/or strengthening of major factors that might minimize inequality, in particular - stimulating business activities in the lagging regions of the country, attracting FDI, simplifying trading procedures, developing financial infrastructure for trade among other measures. The fact that some regional budgets heavily depend on the federal one suggests that the industrial and services sectors in those regions are not full-fledged and/or there is a substantial segment of the non-observed economy. If the latter is true, such territories free-ride on at the expense of more law-abiding ones.
Policy makers should pay attention to factors that impede industrial and infrastructure development. For example, extremely high-interest rates that Russian banks offer are detrimental for business investments. The federal authorities regularly receive such complaints from various Russian regions, but until now they have hardly been properly addressed.

Even though we could not include into the model the education level, it is obvious that allocation of skilled work-force tends to gravitate to the regions with developed industrial and services sectors and higher growth rates which also offer more attractive employment opportunities. Again, a simple idea about the importance of infrastructure and manufacture development re-enforces itself. At the same time, the authors argue that the role of trade should not be underestimated in overcoming regional inequalities. Even though the model showed that trade is not a key factor in inequality problem, it reflects the potential of a given region to participate in international economic activities. It would be of interest to test how economic sanctions influenced trade and inequality levels in Russia regions considering.

Lastly, the authors would like to point out that better statistical data on regional inequality and income distribution will help further research.

\section{References}

1. Fishlow, A. (1995). Inequality, poverty and growth: where do we stand? In: Bruno, M. \& Pleskovic, B. (Eds). Annual World Bank Conference on Development Economics. Washington, D.C.: The World Bank, 25-39.

2. Rodriguez, F. \& Rodrik, D. (2000). Trade Policy and Economic Growth: A Skeptic's Guide to the Cross-National Evidence. In: Bernanke, B. \& Rogoff, K. (Eds). NBER Macro Annual 2000. Cambridge, Massachusetts: National Bureau of Economic Research, 261-338.

3. Berg, A. \& Krueger, A. (2003). Trade, Growth, and Poverty: A Selective Survey. IMF Working Paper WP/03/30, 1-50.

4. Meschi, E. \& Vivarelli, M. (2009). Trade and Income Inequality in Developing Countries. World Development, 37(2), 287-302.doi:10.1016/j.worlddev.2008.06.002

5. Dinopoulos, E. (2008). Trade, globalization and poverty. London: Routledge, 268.

6. Dollar, D. \& Kraay, A. (2001). Trade, Growth, and Poverty. World Bank Policy Research Department Working Paper, $2615,1-45$.

7. Ezcurra, R. \& Rodríguez-Pose, A. (2014). Trade openness and spatial inequality in emerging countries. Spatial Economic Analysis, 9(2), 162-182. doi:10.1080/17421772.2014.891155.

8. Sutyrin, S., Koval, A., \& Trofimenko, O. (2014). Integrating into the multilateral trading system and global value chains: the case of Russia. In: Jansen, M., Jallab, M.S. \& Smeets, M. (Eds). Connecting to global markets. Challenges and opportunities: case studies presented by WTO chair-holders. Geneva: World Trade Organization, 103-115.

9. Alexeev, M. V. \& Gaddy, C. G. (1993). Income distribution in the USSR in the 1980s. Review of Income and Wealth, 39(1), 23-36.

10. Bobkov, V. N. \& Veredyuk, O. V. (2013). Neravenstvo urovnya zhizni naseleniya v Rossii: vnutrenniy i mezhdunarodnyy konteksty (nachalo 1990-h i 2000-e gody). [Inequality of living standards in Russia: Internal and international context (the early 1990s and the 2000s]. Ekonomika regiona [Economy of Region], 3(35), 53-62. (In Russ.)

11. Bourguignon, F. \& Morrisson, C. (1990). Income distribution, development and foreign trade: A cross-sectional analysis. European Economic Review, 34(6), 1113-1132. doi:10.1016/0014-2921(90)90071-6.

12. Santos-Paulino, A. U. (2012). Trade, Income Distribution and Poverty in Developing Countries: A Survey. UNCTAD Discussion Papers 207, 1-30.

13. Goldberg, P. K. \& Pavcnik, N. (2007). Distributional Effects of Globalization in Developing Countries. Journal of Economic Literature, 45(1), 39-82. 
14. Nicita, A. (2009). The price effect of tariff liberalization: Measuring the impact on household welfare. Journal of Development Economics, 89, 19-27. doi: 10.1016/j.jdeveco.2008.06.009.

15. Cerdeiro, D. \& Komaromi, A. (2017). The effect of trade on income and inequality: a cross-sectional approach. IMF Background Papers, 1-7.

16. Meschi, E. \& Vivarelli, M. (2009). Trade and Income Inequality in Developing Countries. World Development, 37, 287-302. doi: 10.1016/j.worlddev.2008.06.002.

17. Furusawa, T. \& Konishi, H. (2016). International Trade and Income Inequality. Boston College Working Papers in Economics, 849, 1-44.

18. Hirte, G. \& Lessmann, Ch. (2014). Trade and Interregional Inequality. 54th Congress of the European Regional Science Association: «Regional development \& globalisation: Best practices». St. Petersburg, European Regional Science Association (ERSA).

19. Daumal, M. (2013). The Impact of Trade Openness on Regional Inequality: The Cases of India and Brazil. The International Trade Journal, 27(3), 243-280. doi: https://doi.org/10.1080/08853908.2013.796839.

20. Wan, G., Lu, M. \& Chen, Zh. (2007). Globalization and regional income inequality: empirical evidence from within China. The review of Income and Wealth, 53(1), 35-59. doi: https://doi.org/10.1111/j.1475-4991.2007.00217.x.

21. Dolinskaya, I. (2002) Transition and Regional Inequality in Russia: Reorganization or Procrastination? International Monetary Fund Working Paper, WP/02/169, 31.

22. Buccellato, T. \& Mickiewicz, T. (2009) Oil and Gas: A Blessing for the Few. Hydrocarbons and Inequality within Regions in Russia. Europe-Asia Studies, 61(3), 385-407. doi: https://doi.org/10.1080/09668130902753275.

23. Yemtsov, R. (2005). Quo Vadis? Inequality and Poverty Dynamics Across Russian Regions. Kanbur, R., Venables, A.J. (Eds). Spatial Inequality and Development. Oxford, Oxford University Press, 348-378.

24. Aisbett, E., Harrison, A. \& Zwane, A. (2007). Globalization and poverty: what is the evidence? In: Harrison, A. (Ed.). Trade, Globalization, and Poverty. London: Routledge, 33-61.

25. Cingano, F. (2014). Trends in Income Inequality and its Impact on Economic Growth. OECD Social, Employment and Migration Working Papers, No. 163, OECD Publishing. Retrieved from: http://dx.doi.org/10.1787/5jxrjncwxv6j-en.

26. Harrison, A. (2006). Globalization and Poverty. NBER Working Paper No. 12347, 1-52.

27. Sutyrin, S. (2007). Doha round of WTO negotiations: prospects and repercussions for Russian Federation. World Journal of Management \& Economics, 1(2), 2-6.

28. Bank of Finland (2012). BOFIT Weekly 22, 1.6.2012.

29. Korgun, I. \& Kumo, K. (2015). Vneshnyaya torgovlya I ekonomicheskoye razvitie rossiyskikh regionov v 2000-2012 gg. [Role of foreign trade in economic development of Russian regions during 2000-2012]. Vestnik Sankt-Peterburgskogo Universiteta. Ekonomika [St Petersburg University Journal of Economic Studies], 2, 47-71. (In Russ.)

30. Kumo, K. (2016). Research on Poverty in Transition Economies: A Meta-analysis on Changes in the Determinants of Poverty. Transition Studies Review, 23 (1), 37-59. doi: http://dx.doi.org/10.14665/1614-4007-23-1-004.

31. Gorodnichenko, Y., Sabirianova, K. \& Stolyarov, D. (2010). Inequality and volatility moderation in Russia: Evidence from micro-level panel data on consumption and income. Review of Economic Dynamics, 13, 209-237. doi:10.1016/j. red.2009.09.006.

32. Denisova, I. (2012). Income Distribution and Poverty in Russia. OECD Social, Employment and Migration Working Papers, 132, 1-46.

33. Fedorov, L. (2002) Regional Inequality and Regional Polarization in Russia, 1990-99. World Development, 30(3), 443-456.

34. World Bank (2005). Russian Federation Reducing Poverty through Growth and Social Policy Reform. Report No. 28923-RU, 187.

35. Rutherford, T. \& Tarr, D. (2008). Regional Household and Poverty Effects of Russia's Accession to the World Trade Organization. World Bank Policy Research Working Paper 4570, 1-83.

36. Afesorgbor, S. K. \& Mahadevan, R. (2016). The Impact of Economic Sanctions on Income Inequality of Target States. World Development, 83, 1-11. doi: 10.1016/j.worlddev.2016.03.015.

37. Zubarevich, N. \& Safronov, S. (2013). Neravenstvo socialno-ehkonomicheskogo razvitiya regionov i gorodov Rossii 2000-h godov: rost ili snizhenie? [The Inequality of Social and Economic development of Regions and Cities of Russia of the 2000s: Growth or Decline?]. Obshchestvennyye nauki i sovremennost [Social Sciences and Contemporary World], 6, 15-26. (In Russ.)

38. Zubarevich, N. (2014). Regionalnoye razvitie i regionalnaya politika v Rossii [Regional Development and Regional Policy in Russia]. EKO [ECO], 4, 7-27.

39. Rodríguez-Pose, A. (2012). Trade and Regional Inequality. Economic Geography, 88(2), 109-136. doi:10.1111/ j.1944-8287.2012.01147.x.

40. Krugman, P. (1980). Scale Economies, Product Differentiation, and the Pattern of Trade. The American Economic Review, 70(5), 950-959.

41. Fujita, M., Krugman, P. \& Venables, T. (1999). The Spatial Economy: Cities, Regions and International Trade. Cambridge, MA: MIT Press.

42. Frankel, J. A. \& Romer, D. (1999). Does Trade Cause Growth? American Economic Review, 89(3), $379-399$. doi:10.1257/aer.89.3.379. 
43. Barro, R. J. (2015). Convergence and Modernisation. The Economic Journal, 125(585), 911-942, doi:10.1111/ ecoj. 12247.

44. Gennaioli, N., Porta, R. L., Lopez-De-Silanes, F., \& Shleifer, A. (2012). Human Capital and Regional Development. The Quarterly Journal of Economics, 128(1), 105-164. doi:10.1093/qje/qjs050.

\section{Authors}

Kazuhiro Kumo - Doctor of Economics, Professor, Institute of Economic Research, Hitotsubashi University (2-1 Naka, Kunitachi, Tokyo, 186-8601 Japan, e-mail: kumo@ier.hit-u.ac.jp).

Aleksandra Gennadyevna Koval - PhD in Economics, Associate Professor, Department of World Economy, SaintPetersburg State University; ORCID: 0000-0001-8648-0911, Researcher ID: O-5493-2014 (62, Chaykovskogo St., SaintPetersburg, 191123, Russian Federation; e-mail: a.koval@spbu.ru).

Irina Aleksandrovna Korgun - PhD in Economics, Invited Researcher, Institute of Russian Studies, Hankuk University of Foreign Studies (South Korea, 02450, Seoul, Imun-ro, Imun 1(il)-dong, Dongdaemun-gu, 107; e-mail: irinakorgun@ yandex.ru).

Olga Yuryevna Trofimenko - PhD in Economics, Associate Professor, Department of World Economy, SaintPetersburg State University; Scopus Author ID: 14123924100; ORCID: 0000-0001-7035-3379; Researcher ID: F-7577-2015 (62, Chaykovskogo St., Saint-Petersburg, 191123, Russian Federation; e-mail: o.trofimenko@spbu.ru). 